\title{
Revisiting the reasons for contact fatigue defects in rails
}

\author{
Alexander Darenskiy ${ }^{1 *}$, Dmitry Potapov ${ }^{1}$, Yuseph Tuley ${ }^{2}$, Natalia Bugaets ${ }^{1}$ and Alina \\ Malishevskaya $^{1}$ \\ ${ }^{1}$ Department of Track and Track Facilities, Ukrainian State University of Railway Transport, \\ Feierbakh Square 7, 61050, Kharkiv, Ukraine \\ ${ }^{2}$ Track Department JSC "Ukrzaliznytsia", Tverska Street 5, 03150, Kyiv, Ukraine
}

\begin{abstract}
As it is known rail is one of the most significant elements of the whole railway construction. Operation under alternating loads from wheels of the rolling stock and different ambient temperatures lead to appearance and development of rail defects and damages. A great variety of operational factors (freight traffic density, axial loads, traffic speeds, track layout and profile) as well as special features of manufacturing and thermal treatment of rails create certain difficulties while identifying reasons for defects and damages. The article deals with an attempt to estimate influence of track layout and lateral forces on appearance of defects and damages in rails on the base of long-term observations of rail operation in Kharkiv Metro. On the basis of the vehicle/track mathematical model which considers structural features of both rolling stock and permanent way in underground systems, the level of lateral forces in curves was calculated. The coefficients of correlation between the track curvature, the level of forces and the amount of defected rails removed were later obtained, that made it possible to determine the dominant factor which may lead to appearance and development of contact fatigue defects in rails laid in curves.
\end{abstract}

\section{Introduction}

In order to provide the optimal level of aggregate costs for track maintenance it is necessary to solve the problem of longer life of all elements of the permanent way, first and foremost, the rail, being the most expensive and vital one.

The problem can only be solved if all reasons for failures in these elements are definitely established, that will make it possible to plan and implement measures aimed at effective solutions.

The life cycle of rails now is determined, mostly, by failures due to defects and damages in rails, first of all, of contact fatigue nature. The study attempts to establish reasons for appearance of contact fatigue defects in rails by the example of Kharkiv Metro. The research presented in [1-6] establishes that the principle reason for appearance of these defects is insufficient metal strength. However, the long-term observations, conducted by the authors of the article, have revealed that a large number of defects have appeared in

* Corresponding author: ppx xiit@kart.edu.ua 
curves on the track. But studies [1-6] do not provide an answer to the question about the reason for a significant number of defects in curves.

The issue of a life cycle of rails in underground systems in Ukraine is the theme of the above-mentioned studies. It should be noted that foreign studies [7-16], while paying attention to high intensity of defect appearance in curves, do not uniquely answer the question about the reason for the phenomena. Thus, investigation into the reasons for contact fatigue defects in rails has to be continued.

The objective of the study is to reveal reasons for contact fatigue defects in rails by the example of Kharkiv Metro. The results of long-term observations of rail operations, numerical research into the train/track dynamics in underground systems with application of the theory of probability methods for generalization of results are on the basis of this research.

\section{The basic part}

Nowadays Kharkiv Metro includes three lines. The track mileage of main lines is approximately $75 \mathrm{~km}$ (about $20 \mathrm{~km}$ of them are curves, the radii being from 350 to $3000 \mathrm{~m}$ ).

The basic regulation in force for Ukraine's metro systems which establishes the type of a rail defect and also regulates the rail rolling stock operation on rails with defects and damages is the Classification and Catalogue of Defects and Damages in Rails on Ukrainian Railways. All defects and damages in the Classification are coded as three digital units.

Table 1. Rail defects by the Classification in force

\begin{tabular}{|l|l|}
\hline $\begin{array}{c}\text { Name of the defect and main reasons for } \\
\text { appearance and development }\end{array}$ & $\begin{array}{c}\text { Digital code } \\
\text { of defect }\end{array}$ \\
$\begin{array}{l}\text { the layer separation and spalling of metal on } \\
\text { the rolling surface due to breakdowns in the } \\
\text { manufacturing technology }\end{array}$ & $\begin{array}{l}\text { the metal spalling on the corners due to } \\
\text { insufficient contact fatigue metal strength }\end{array}$ \\
\hline $\begin{array}{l}\text { cross cracks in the railhead in form of bright } \\
\text { and dark spots and fractures as a result of } \\
\text { insufficient contact fatigue metal strength }\end{array}$ \\
\hline $\begin{array}{l}\text { corrosion, scorching or local wear of rail foot } \\
\text { and fatigue cracks leading to them }\end{array}$
\end{tabular}

The structure of the code is as follows: the first digit stands for the type of a defect or damage, it also indicates the location in the cross-section (rail head, rail web, rail foot), the second digit stands for the kind of a defect or damage indicating reasons for the appearance and propagation, and the third digit determines the defect or damage location along the rail. 
The first two digits of the code are separated from the third one by a point mark. The diagram and the description of the most typical defects and damages in rails for Kharkiv Metro are presented in Table 1.Results of observations of rail operation in Kharkiv Metro revealed that from 1986 to 2001 the main rail defects were ones by code 11.1-2-3. This state was the most characteristic for lines I and II, where the number of rails removed due to this defect was $60 \%$ of the total number of rails removed. The conclusion regarding line III was not made due to lack of the statistical information.

Besides, it has been established that the track layout also impacts the appearance of contact fatigue defects in rails, all other operational factors being constant. The less the radius of the curve is the more the damageability of rails in terms of this defect.

During 2002-2012 the total number of rails removed by code 11 was already $73.24 \%$ out of all rails removed (763 units). There exists a trend of a greater number of defected rails due to this defect if the radius of the track decreases. In curves the defected rails removed accounted for $48.05 \%$, for straight sections it was $25.19 \%$.

The final confirmation of the conclusions about the basic defect types in rails on main lines in Kharkiv Metro is the data on the rails removed from January 2012 till October 2014. The analysis conducted established the following:

- rail defects by code $11.1-3$ was $55 \%$ (line I $-35.63 \%$, line II $-13.75 \%$, line III $-5.62 \%$ )

- rail defects by code $10.1-3$ was $14.38 \%$ (line I $-8.75 \%$, line II $-5.63 \%$, line III $-3.12 \%$ )

- rail defects by code 69 was $6.25 \%$ (all these rails were removed from line I).

During this period with the help of the defectoscopy means the following was detected: two rails with defects by code 21.2 which accounted for $1.25 \%$ out of the total number.

The removal of rails in curves (Fig. 1) by the main defect (code 11) was $37.5 \%$. And for straight sections the number of rails removed was only $17.5 \%$ which again confirmed the influence of the track layout on the appearance of defects in rails.

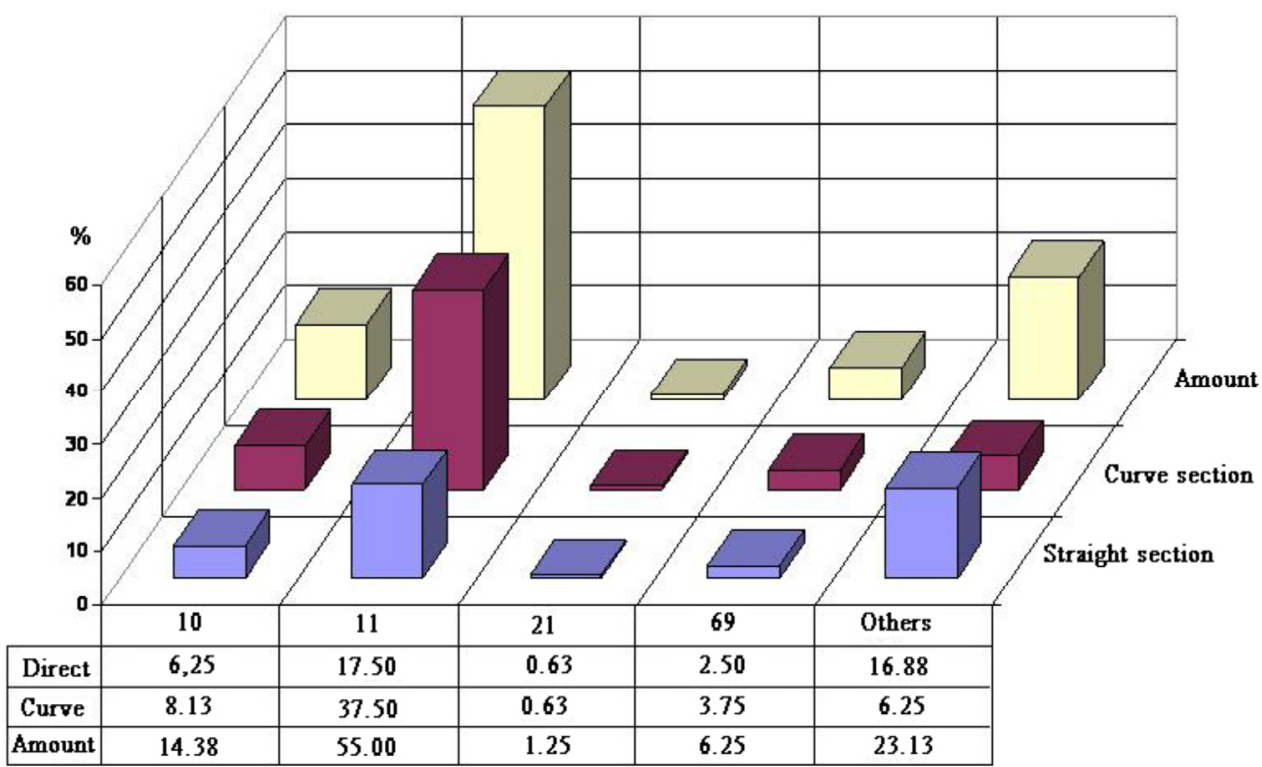

Fig. 1. The total number of rails removed in Kharkiv Metro in dependency on the track layout.

The analysis conducted on the basis of the information obtained brought to an assumption about the main reason for contact fatigue defects in rails, which is the impact of horizontal transverse forces.

It should be noted that experimental determination of these forces even for main line railways are rather costly and time consuming, besides it does not provide a definite answer 
to the question about the influence of rolling stock characteristics on the level of these forces as the input data (actual speed values, axial loads, stiffness of spring groups, etc.) cannot be virtually determined. For underground systems owing to narrow circumstances these work is practically impossible. Therefore the authors made a solution on conducting numerical research into the dynamic vertical and horizontal transverse forces for underground systems. Thus, a mathematical model of the spatial vehicle/track dynamic system was developed in order to solve the problem [20].

A large amount of research, which considers the problems of the train/track interaction on main line railways in order to determine the level of vertical, horizontal longitudinal and transverse forces influencing the track in train operation along straight lines and curves, applies only two-dimensional mathematical models of vehicles.

Besides, while determining forces of the train/track interaction, the vertical and horizontal stiffness of track is taken as constant. However, the analysis of features of arrangements and track operation under the influence of rolling stock in underground systems shows that such an assumption cannot be taken.

It should also be noted that presence of curves of small radii, structural features and operational modes of rolling stock in underground systems require consideration of significant nonlinear dependencies, including ones of the tearing type. Since the principle of superposition cannot be applied for nonlinear systems, the authors proposed a nonlinear spatial model of the vehicle.

In the mathematical model, the design scheme of a four-axle vehicle considers the basic structural characteristics of underground cars of the types Ezh3, Em-508T, 81-717, 81-714, 81-718, 81-719, namely:

- the two-stage spring suspension;

- all the wheel sets are leading;

- tractive and braking efforts from the wheel sets to the body frame transfer through the traction drive unit.

Considering all the above-mentioned the spatial vibrations of elements of the "vehicle" subsystem are described with a system of 44 differential second-order equations.

Unlike known mathematical models the "track" subsystem was presented as a spatial structure of rail bars rested on numerous elastic and dissipative supports of nonlinear characteristics. The forced vibrations of rails under the influence of loads from the rolling stock were described with a system of ten equations for rail vibrations in the vertical plane and ten equations for rail vibrations in the horizontal cross plane. And the bend of rails combined with torsion was also considered [23], as well as the distributed rail mass.

The spatial elastic and dissipative characteristics of rail supports were defined on the basis of the analytical analysis of operation of the "Metro" type fastenings and the experiments conducted [17-19]. A mathematical model of the spatial vehicle/track dynamic system was applied in Mathcad software.

The summarized results of actual loads from underground cars on track are presented in Table 2 .

In order to determine the influence of the layout (track curvature) and horizontal lateral forces on appearance of contact fatigue defects in rails, the statistic treatment of the observation data in terms of the number of rails removed and the data of numerical research into horizontal lateral forces for establishing a level of the influence of these parameters on the damage rate were conducted.

The correlation coefficient was taken as a criterion for determination of an influence level. 
Table 2. Design values of vertical and lateral forces influencing the rail head from the rolling stock in Kharkiv Metro.

\begin{tabular}{|c|c|c|c|c|c|c|c|}
\hline & \multirow{3}{*}{$\begin{array}{c}\text { Radius, } \\
\mathrm{m}\end{array}$} & \multirow{3}{*}{$\begin{array}{l}\text { Value of elevation } \\
\text { of } \\
\text { the high rail, mm }\end{array}$} & \multirow{3}{*}{$\begin{array}{l}\text { Speed, } \\
\mathrm{km} / \mathrm{h}\end{array}$} & \multicolumn{4}{|c|}{ Values of loads obtained, $N$} \\
\hline & & & & \multicolumn{2}{|c|}{ Vertical } & \multicolumn{2}{|c|}{$\begin{array}{c}\text { Horizontal } \\
\text { (lateral) }\end{array}$} \\
\hline & & & & $\min$ & $\max$ & $\min$ & $\max$ \\
\hline 1 & \multirow{3}{*}{400} & \multirow{3}{*}{120} & 80 & 35746 & 83856 & 4630.3 & 9891.8 \\
\hline 2 & & & 60 & 42033 & 75866 & -1584 & -722.24 \\
\hline 3 & & & 40 & 51620 & 75293 & -9707.2 & -4574.8 \\
\hline 4 & \multirow{3}{*}{500} & \multirow{3}{*}{120} & 80 & 35968 & 84559 & 2047 & 4367.7 \\
\hline 5 & & & 60 & 42015 & 76297 & -4620.6 & -2201.3 \\
\hline 6 & & & 40 & 50967 & 75941 & -10891 & -5154.7 \\
\hline 10 & \multirow{3}{*}{600} & \multirow{3}{*}{120} & 80 & 36081 & 84792 & 297.41 & 868.84 \\
\hline 11 & & & 60 & 42327 & 76219 & -6544.7 & -3151.2 \\
\hline 12 & & & 40 & 50958 & 75462 & -11867 & -5645.7 \\
\hline 16 & \multirow{3}{*}{800} & \multirow{3}{*}{90} & 80 & 35911 & 84917 & 283.32 & 691.78 \\
\hline 17 & & & 60 & 42290 & 75927 & -4983 & -2355.6 \\
\hline 18 & & & 40 & 50863 & 75763 & -8792.8 & -4153.5 \\
\hline 22 & \multirow{3}{*}{1000} & \multirow{3}{*}{80} & 80 & 36106 & 84829 & -505.78 & -266.61 \\
\hline 23 & & & 60 & 42200 & 76164 & -5017.2 & -2415 \\
\hline 24 & & & 40 & 50641 & 75408 & -8107.3 & -3816.5 \\
\hline 25 & \multirow{3}{*}{1500} & \multirow{3}{*}{70} & 80 & 36331 & 85007 & -2591.3 & -1203.7 \\
\hline 26 & & & 60 & 41851 & 76427 & -5590.5 & -2698.2 \\
\hline 27 & & & 40 & 51099 & 75670 & -7633.6 & -3609.2 \\
\hline 31 & \multirow{3}{*}{ straight } & \multirow{3}{*}{0} & 80 & 36026 & 84881 & & \\
\hline 32 & & & 60 & 42087 & 75770 & & \\
\hline 33 & & & 40 & 50804 & 76030 & & \\
\hline
\end{tabular}

This criterion was calculated according to $[21,22]$ from the expression:

$$
r=\frac{\sum x_{i} \cdot y_{i}-k \cdot \bar{x} \cdot \bar{y}}{\sqrt{\sum x_{i}^{2}-k \cdot \bar{y}^{2}} \cdot \sqrt{\sum y_{i}^{2}-k \cdot \bar{x}^{2}}}
$$

where $x_{i}$ is the value of argument (track curvature or the value of lateral forces);

$y_{i}$ is the value of function (damageability of rails by contact fatigue defects);

$\bar{x}$ is the average value of argument;

$\bar{y}$ is the average value of function;

$k$ is the number of observation points.

The significance of the correlation coefficient was checked by Kolmogorov's criterion

$$
r \cdot \sqrt{k-1} \geq T
$$

where $T$ is the table value of random deviations of products $r \cdot \sqrt{k-1}$ from zero [21, 22].

The correlation coefficients obtained for the values under investigation for all three lines of Kharkiv Metro are presented in Table 3. Table 4 presents the results of validation of the correlation coefficients obtained. 
Table 3. Values of coefficients of correlation between the track curvature, lateral forces and the number or defected rails removed.

\begin{tabular}{|l|c|c|c|c|}
\hline \multirow{2}{*}{ Factor } & \multicolumn{4}{|c|}{ Values of correlation coefficients } \\
\cline { 2 - 5 } & Line I & Line II & Line III & $\begin{array}{c}\text { throughout } \\
\text { the Metro }\end{array}$ \\
\hline Track curvature & 0.302 & 0.200 & 0.262 & 0.323 \\
\hline $\begin{array}{l}\text { Level of lateral } \\
\text { forces }\end{array}$ & 0.748 & 0.262 & 0.394 & 0.354 \\
\hline
\end{tabular}

Table 4. Validation of correlation coefficients.

\begin{tabular}{|c|l|c|c|c|}
\hline \multirow{2}{*}{ Line number } & Dependency & $\begin{array}{c}\text { Number of } \\
\text { observations }\end{array}$ & $\begin{array}{c}\text { Value of } \\
r \cdot \sqrt{k-1}\end{array}$ & $\begin{array}{c}\text { Table value of } \\
\text { random } \\
\text { deviations, } T\end{array}$ \\
\hline \multirow{2}{*}{ Line I } & track curvature & 48 & 2.07 & 1.95 \\
\cline { 2 - 5 } & lateral forces & 48 & 5.12 & 1.95 \\
\hline \multirow{2}{*}{ Line II } & track curvature & 29 & 1.06 & 0.95 \\
\cline { 2 - 5 } & lateral forces & 29 & 1.39 & 0.95 \\
\hline \multirow{2}{*}{ Line III } & track curvature & 34 & 1.51 & 1.21 \\
\cline { 2 - 5 } & lateral forces & 34 & 2.26 & 1.21 \\
\hline \multirow{2}{*}{$\begin{array}{l}\text { throughout } \\
\text { Metro }\end{array}$} & thack curvature & 111 & 3.38 & 3.01 \\
\cline { 2 - 5 } & lateral forces & 111 & 3.71 & 3.01 \\
\hline
\end{tabular}

The analysis of values in Tables 3 and Tables 4 shows that values of the coefficients of correlation between the level of lateral forces and the number of defected rails removed 10$148 \%$ higher than values of the coefficients of correlation between the track curvature and the number of rails removed. The test of significance for correlation coefficients showed that design values were considerably higher than table critical ones. The most obvious is the value of the coefficient of correlation between the level of lateral forces and the number of defected rails removed for line I of Kharkiv Metro, which is in operation for over 40 years.

\section{Conclusions}

1. The research into the correlation coefficient has shown that the level of lateral forces is the most significant reason for appearance of contact fatigue defects by code 11 for rails in Kharkiv Metro.

2. The results of the research make it possible to give grounded recommendations about the change in operational characteristics of curves for underground systems in Ukraine in order to lower the susceptibility to contact fatigue defects. It deals with admissible traffic speeds and elevation of the high rail in curves of different radii, as well as possible correction of these parameters.

3. The research conducted can serve as the basis for development of recommendations on frequency of track maintenance works.

\section{References}

1. R.M. Yosifovich, Naukove obgruntuvannya i praktichne virishennya problemi pidvishchennya ekspluatatsiynogo resursu reyok Kï̈vs'kogo metropolitenu. PhD Thesis, DETUT, 24 (2015).

2. E.I. Danilenko, R.M. Yosifovich, O.A. Oliynik, O.O. Soroka, Zb. nauk. prats' DETUT. Seriya «Transportni sistemi i tekhnologii», (22), 10-20 (2013). 
3. V.V. Kosarchuk, O.V. Agarkov, Zb. nauk. prats' DETUT. Seriya «Transportni sistemi i tekhnologii», (18), 61-72 (2011).

4. V.V. Kosarchuk, A. V. Agarkov, Zb. nauk. prats' DETUT. Seriya «Transportni sistemi i tekhnologii», (20), 77-89, (2012).

5. O.V. Agarkov, R.M. Yosifovich, «Science and Transport Progress». Bulletin of Dnipropetrovsk National University of Railway Transport, 4(58), 71-86, (2015).

6. R.M. Yosifovich, «Science and Transport Progress». Bulletin of Dnipropetrovsk National University of Railway Transport, 6 (60), 36-41 (2015).

7. S.L. Grassie, J. Kalousek, Proceedings of 6th International Heavy Haul Conference, The International Heavy Haul Association, Cape Town, South Africa, 381-404 (1997).

8. J.W. Ringsberg, H. Bjarnehed, A. Johansson, B.L. Josefson, Proceedings of the Institution of Mechanical Engineers, Part F: Journal of Rail and Rapid Transit, 1(214), 7-19 (2000).

9. M. Taraf, E.H. Zahaf, O. Oussouaddi, A. Zeghloul, Tribology International, 3(43), 585-593 (2010).

10. A. Johansson, B. Palsson, M. Ekh, J.C. Nielsen, M.K. Ander, J. Brouzoulis, E. Kassa, Wear, 1(271), 472-481 (2011).

11. V.V. Kuznetsov, V. S. Lysyuk, Vestnik VNIIZhTa. 6, 69-94 (2000).

12. M.F. Verigo, Vestnik VNIIZhTa, 21 (5), 25-37 (2001).

13. A.Yu. Abdurashitov, Put' i putevoe khozyaystvo, 11, 16-20 (2002).

14. M.Kh. Akhmetzyanov, Vestnik VNIIZhT, 2, 36-43 (2003).

15. Beli, Ya., I. Nemet, Put' i putevoe khozyaystvo, 5, 33-37 (2011).

16. A.Yu. Abdurashitov, Put' i putevoe khozyaystvo, 11, 16-20 (2002).

17. A.S. Malishevskaya, D.A. Fast, Ivanovo: Nauchnyy mir, 2, 48-55 (2015).

18. A.S. Malishevskaya, Zb. nauk. prats'. Ukraïns'kogo derzhavnogo universitetu zaliznichnogo transportu, 161, 55 - 60 (2016).

19. O.M. Darenskiy, Yu.L. Tuley, D.O. Potapov, A.S. Malishevs'ka, «Science and Transport Progress». Bulletin of Dnipropetrovsk National University of Railway Transport, 6(66), 96-104 (2016).

20. O.M. Darenskiy, A.S. Malishevs'ka, Information and control systems at railway transport, 6, 56-64 (2016).

21. M.N. Stepnov, Statisticheskie metody obrabotki rezul'tatov mekhanicheskikh ispytaniy. Moscow, 232 (1985).

22. K.A. Braunli, Statisticheskaya teoriya i metodologiya v nauke i tekhnike. Moscow, 408 (1977).

23. A.N. Darenskiy, Ya.S. Leybuk Information and control systems at railway transport, 2(123), 52-60 (2017). 